\title{
Increasing the Competitiveness of Market Value Chains be Shaped to Improve Nutrition for Smallholder Producers: A Review
}

\author{
Saurabh Tyagi ${ }^{1 *}$, R.K. Naresh ${ }^{2}$, A.P. Garg ${ }^{3}$, M. Moni ${ }^{4}$ and Abhishek Kumar ${ }^{5}$ \\ ${ }^{1}$ Department of Agriculture, Shobhit University, Meerut, U. P., India \\ ${ }^{2}$ Department of Agronomy, Sardar Vallabhbhai Patel University of Agriculture \& Technology, \\ Meerut, U.P., India \\ ${ }^{3}$ Department of Biological Engineering \& Life Sciences, Shobhit University Meerut, U.P., \\ India \\ ${ }^{4}$ Department of Agriculture Informatics \& e-Governance Research Studies(CAIRS), Shobhit \\ University, Meerut \& NCR Delhi, India \\ ${ }^{5}$ Department of Business Studies, Shobhit University Meerut, U.P., India \\ *Corresponding author
}

\section{Keywords \\ Nutrition, Diets, Market chain, \\ Business \\ environment, Development practice}

\section{Article Info}

Accepted:

17 October 2019

Available Online:

10 November 2019

\section{A B S T R A C T}

Sustained economic and income growth, a fast growing urban population, and the increasing integration of global agri-food markets are fuelling rapid growth in demand for high-value food commodities in India. This is an opportunity for farmers, especially smallholder farmers, in India to augment their incomes and use surplus family labour in the production of high-value, labour-intensive food commodities. The transition to high-value agriculture, however, is unlikely to be smooth. One of the major impediments is smallholders' lack of access to markets for high-value commodities. Local rural markets are thin, and trading in distant urban markets is not remunerative owing to high transportation and transaction costs. Besides, they also face problems in gaining access to credit, high quality inputs, improved technology, information, and services. Improving smallholders' access to markets requires close linkages between farmers, processors, traders, and retailers to coordinate supply and demand. The worldwide importance of crop production is undisputed due to its function for basic nutrition of billions of people. Yet, the emergence of global forces implies severe consequences for the organization of market value chains. These forces particularly include processes of liberalization and deregulation, the dominance of large retail groups as well as ever-changing consumer demands, leading to continuous reconfigurations of market value chains. Changes in the global agricultural economy are providing smallholders with new opportunities that also present new constraints. The demand for higher value and processed foods as well as the rise of supermarkets around the world has implications for the entire food marketing system as it alters procurement systems and introduces new quality and safety standards. Marketing systems are undergoing rapid transformation. Traditional marketing channels with ad hoc sales are being replaced by coordinated links between farmers, processors, retailers and others. As incomes increase, food consumption patterns are changing, with a greater emphasis on meat, dairy products and fruits and vegetables. Consumers are becoming more demanding in terms of quality and safety and demographic and income trends are leading to increased demand for convenience foods, together with assurances of product safety. Income growth alone cannot solve the problem of malnutrition and may in fact create problems linked to overweight and obesity. The challenge from the nutrition perspective is how to sustainably improve the quality of diets, as well as other health-nutrition related behaviours, across different populations and age groups? Overall, we could extract three strands of literature on global crop value chains: the integration of smallholders; the role of food standards; and the effect of 'hidden' dynamics Value chain approaches can provide useful frameworks to examine the food system and the potential to achieve improved nutritional outcomes by leveraging market-based systems. However, understanding the links between value chains, the overall business environment in which they operate, and nutrition among targeted populations is complex, involving actors and activities working across agriculture, health and nutrition, and very little evidence exists on the potential or the trade-offs involved. 


\section{Introduction}

Many of the world's poor still directly or indirectly depend on agriculture for their livelihoods, most of them as small scale farmers. Besides building up farmers' production capabilities, improving their access to markets has become a key element in strategies to promote rural development and poverty reduction. In order to be successful, development programs have to address the multiple market failures that the small farm sector suffers from (Jayne et al., 2010). In particular, small-scale farmers face many constraints that impede them from taking advantage of market opportunities. Often living in remote areas with poor infrastructure, they face high transaction costs that significantly reduce their incentives for market participation (Barrett, 2008). This holds true for both agricultural input and output markets. In addition, small farms with few assets often have limited access to services, including effective extension and rural credit, which are important preconditions for upgrading production systems (Wiggins et al., 2010). Farmer organizations, cooperatives, and similar forms of collective action are avenues to reduce high transaction costs (Hellin and Dohrn, 2008).

They can be oriented toward improving production, marketing, or livelihoods in general, sometimes serving more than one purpose (Francesconi and Heerink, 2011). The promotion of farmer organizations through outside assistance has recently re-gained popularity in the context of the agro-food system transformation (Rao and Qaim, 2011), which is characterized by a growing role of supermarkets and high value exports. Emerging high-value chains often involve strict standards and new procurement systems of agribusiness companies- factors that may further exacerbate market access for small farms (Reardon et al., 2009).
Traditionally farmers have made decisions on what they should grow, what they should keep for home consumption, and what they are able to sell at the marketplace. In former times sales would have centred on local markets and it would have been rare for a farmer to venture far afield in search of new market opportunities or to consider developing new, higher value products. This traditional form of agriculture starts to change as communities and nations begin to modernize. Through processes of urbanization, generally fostered by industrialization, demand for food from urban dwellers becomes dependent upon more sophisticated arrangements that require aggregation of farm produce, transportation, storage, wholesaling, processing, and retailing. As cities expand, food supply systems develop into increasingly longer and more complex market chains with many market channels and specialization of roles in the market chain based on product type, levels of added value and market segmentation.

In most cases marketing system work well, however problems can occur in the food supply system when there are shocks, such as severe drought, floods, major disease outbreaks or civil unrest which can disrupt market supplies. In the case of agricultural markets, problems also occur due to seasonal effects, which can be exacerbated by the lag time between farmers observing a price trend or opportunity and being able to respond, after making decisions to plant, grow, and harvest a specific crop or to rear animals. Consequently, changes in market supply conditions in one year can lead to major swings in the supply and demand of agricultural goods in subsequent years. This is sometimes referred to as boom to bust marketing cycles. In an attempt to avoid problems in food supplies and reduce price volatility within the agricultural marketplace, governments in many countries have taken it upon themselves to regulate the market, setting up support 
measures such as subsidies, floor prices, and quotas for specific commodities in an attempt to match demand with supply.

Improving smallholders' access to markets requires close linkages between farmers, processors, traders, and retailers to coordinate supply and demand. Institutions such as cooperatives, producers' associations, and contract farming are important means of linking producers with markets, as well as a source of credit, inputs, technology, information, and services. But there is concern that smallholders may be excluded from the institution-driven value chains. Agribusiness firms, to reduce the transaction costs of contracting with a large number of smallholders, have tended to contract with a few large producers who can supply large volumes and are capable of complying with food-quality standards. There is also a fear that agribusiness firms may exploit smallholders by extracting monopsonistic rent in the output market and manipulating the terms and conditions of contracts.

The reviewed guides utilize different terms to describe market actors and the arrangements for production and marketing of agricultural products and services. Among the terms used are value chain, supply chain, market system, market chain, and agro-food chain.

Value chain as a set of activities: various guides base their definition on activities. World Bank (2010) provides an illustrative example: "The term value chain describes the full range of value adding activities required to bring a product or service through the different phases of production, including procurement of raw materials and other inputs."

Value chain as a set of actors: other guides base their definition on actors. For example, UNIDO (2011) defines a value chain as "actors connected along a chain producing, transforming, and bringing goods and services to end-consumers through a sequenced set of activities."

Value chain as a strategic network: in this case, value chains do not simply exist in a particular space, but are built for the purpose of responding better to consumer demand. Borrowing from Hobbs, Cooney, and Fulton (2000), CIAT (2007) defines value chains as a strategic network among a number of independent business organizations, where network members engage in extensive collaboration. DFID (2008) defines a market system as a "multiplayer, multi-function arrangement comprising three main sets of functions (core, rules, and supporting) undertaken by different players... through which exchange takes place, develops, adapts, and grows."

As incomes increase, food consumption is changing. Demand for fruits and vegetables, animal products and oil crops is growing and farmers are diversifying production to respond to this. Consumers are also becoming more demanding in terms of quality and safety and demographic and income trends are leading more affluent consumers to demand convenience foods such as frozen, pre-cut, pre-cooked and ready-to-eat items, together with assurances of product safety. Production, processing and distribution systems have been adapting to reflect this. These trends offer considerable threats for farmers, especially small, asset-poor and unorganized farmers, but, for the more efficient ones at least, may also present many opportunities. It is against this background that donors, nongovernmental organizations (NGOs) and others are recognizing that the traditional agricultural assistance projects that concentrated on building up farmers' production capabilities are no longer sufficient to ensure sustainable income growth (if, 
indeed, they ever were). There is now an increasing understanding that production support activities must be linked to market demand and that production activities must be looked at within the context of the whole supply chain and the linkages, or business relations, within that chain. Thus concepts such as "Linking Producers to Markets" or "Linking Farmers with Markets" are very much in vogue. However, while the underlying ideas of those working with farmers may now be more realistic, little will be achieved unless the approach adopted is also realistic. In particular, organizations must be prepared to adopt a much more commercial approach than hitherto, employing staff with a strong understanding of marketing and of the functioning of the private sector.

"Linking farmers to markets" can embrace a whole range of activities, from the very small and localized to the very large. The concept does, however, assume the development of long-term business relationships rather than support for ad hoc sales. This mirrors trends in developed country markets, where there has been a rapid shift from sales through open markets to direct sales that involve linkages and alliances from production to consumption.

At the simplest level agricultural extension workers in developing countries can link farmers to buyers by identifying traders and arranging for them to meet with the farmers, or small-scale traders themselves can seek out new suppliers or can work with existing suppliers to develop new or improved products.

At a more complex level is the work carried out by NGOs and others to identify markets for particular products and organize farmers into groups to supply those markets, or the activities of agro-processors to secure their raw material supply from small farmers. Larger scale contract farming or out-grower programmes may involve considerable longterm investment on the part of the companies and farmers. Discussions in this paper touch on the whole range of such linkage activities.

\section{Value chain development (VCD)}

Patrawart (2007), to facilitate value creation and market access, smallholder farmer organizations need to develop cooperation with external partners, and a partnership platform for all related actors to play roles and share resources and capabilities. Similarly, to enable cooperatives and community enterprises to adopt Inclusive Business Model, collaborative platform has been constructed to allow related organizations to take part in upgrading capabilities of the enterprises, thereby enhancing their ability to increase the price premium and competitiveness in today's market system. Based on this concept, platform creation involves three key dimensions (Fig. 1): Developing entrepreneurial leaders based on fourdimensional characteristics, cooperative spirit; Improving business operation through strategic management; and Utilizing integrated supply chain management and the fair trade principle.

Smallholder farmers often lack of experience in modern agri-business, entrepreneurial mind-set, and managerial skills. To facilitate adoption of VCD by farmer organizations, these internal characteristics of participants need to be upgraded in order to prepare them for business development, value creation, and upgrading process.

Farmer organizations normally use conventional channels to distribute and market their commodities and products. This is based on the traditional perception of farmer organization to separate trading function have to invest in trade and logistics infrastructures as well as capital to finance their purchasing/ 
bargaining power and distribution costs. A limited number of farmer organizations that are capable of adopting VCD should thus be selected and supported taking into account their readiness.

Technological transfer and product innovation will be helpful for zero-waste management of agricultural supplies and the problem of contract-farming in which some buyers cannot accept all of the produce from farmermembers. VCD adoption by farmer organizations should thus be developed in parallel with product innovation together with knowledge / technical partners.

The expression 'Value Chain' means a vertical interaction or a strategic network within different players among a specific supply chain (Hobbs et al., 2000). A FVC is the sum of those processes useful to bring a food product from conception, through the different phases of production, until the delivery of goods to final consumers (Hawkes et al., 2012). FVCs are typical structured networks including equipment dealers, seed suppliers, food processors, distributors and even government regulators, consumers (De Pee et al., 2017).

\section{Institutional innovations linking farmers to markets}

Smallholders are the largest investors in smallholder agriculture. Their system of production is both complex and dynamic. In order to design policies that effectively support their own investments it is necessary to have a picture of some of the key features of smallholder agriculture that relate to investments. The diversity of possible income flows in an agricultural holding and of possible sources of investment (Fig. 2). For smallholders to benefit from the growing market opportunities, close linkages between farmers, processors, traders, and retailers are needed to coordinate supply and demand Vertical coordination of agri-food markets through institutions like cooperatives, producers' associations, and contract farming can help create such linkages.

Labour is a key feature of smallholder agriculture. We consider a smallholding to be an agricultural holding run by a family using mostly their own labour and deriving from that work a large but variable share of its income, in kind or in cash. The family relies on its agricultural activities for at least part of the food consumed - be it through selfprovision, non-monetary exchanges or market exchanges. The family members also engage in activities other than farming, locally or through migration. The holding relies on family labour with limited reliance on temporary hired labour, but may be engaged in labour exchanges within the neighbourhood or a wider kinship framework. Reciprocal relationships are important here for product or productive factor exchanges. An agricultural holding is an economic unit of agricultural production under single management comprising all livestock kept and all land used wholly or partly for agricultural production purposes, without regard to title, legal form, or size. Single management may be exercised by an individual or household, jointly by two or more individuals or households, by a clan or tribe, or by a juridical person such as a corporation, cooperative or government agency.

The holding's land may consist of one or more parcels, located in one or more separate areas or in one or more territorial or administrative divisions, providing the parcels share the same production means utilized by the holding, such as labour, farm buildings, machinery or draught animals (FAO, 1995). A smallholding is "small" because resources are scarce, especially land, and using it to generate a level of income that helps fulfil basic needs and 
achieve a sustainable livelihood consequently require a high level of total factor productivity, requiring in turn a significant level of investment.

These institutions, if managed well, can provide several benefits to farmers besides access to markets. The major benefit consists of reduced transportation and transaction costs. Farmers also benefit from the provision of high-quality inputs, improved technologies, credit, insurance, and support services from the processing or marketing firms provided as a part of contracts.

Agriculture in India is a state subject. The marketing of agricultural produce is governed by the state-specific Agricultural Produce Market Committee [APMC] Acts, which until recently restricted commercial transactions in agricultural commodities outside the statedesignated markets. Under its economic reform program, the central government came with a new Model Agricultural Marketing Act in 2003, which allows allow agribusiness and marketing firms to source their raw materials directly from farmers through contracts or other arrangements. Downstream from this vertical coordination, a significant change is taking place in India's food retailing system in the form of the rise of supermarkets (Fig. 2). A number of large business houses have entered organized food retailing. This move is likely to have a significant impact on food procurement, as well as on traditional retailing systems. Supermarket chains are qualitydriven. There is concern that smallholders may be unable to meet supermarkets' quantitative and qualitative requirements and thus may be displaced from the high-value market segment. There is also concern that the rise of supermarkets in food retailing could displace millions of workers in the unorganized retail food sector. On account of these concerns, India prohibits foreign direct investment in multi-brand retailing. It is also feared that foreign investors may import goods into India, which could be detrimental to domestic producers.

Although the size of the holding is a debatable proxy, available data show a clear and strong picture. According to IFAD, (2013) there are an estimated 500 million smallholder farms in the developing world, supporting almost 2 billion people who depend on them for their livelihood, and these small farms produce about 80 per cent of the food consumed (Hazell, 2011). The role of smallholder agriculture in wider processes of development is the same everywhere. However, smallholder agriculture intersects with issues of (relative) poverty, contributions to food security and food sovereignty, economic growth and broader rural development issues in almost all countries. Investment in smallholder agriculture, therefore, is needed in all countries (Fig. 3).

In synthesis, SFVCs are the engine for enhancing working conditions, improving financial, environmental, social and farmers' performance, enabling environment, increasing consumer benefits, and intensify taxes revenues (Fig. 4). This process can also support rural development around the world, leading to the reduction of hunger, inequality and finally stabilizing migration flows (FAO 2014c). Without a fair distribution of profitability, the weaker partners, usually the rural ones will not survive. More sustainable FVCs imply a bottom-up approach followed by all economic actors, pointing out that the needs of entrepreneurs, managers and farmers should be moved by greater environmental and social awareness and higher pro-activity in cooperation and innovation (Porter, Kramer, 2011). Sustainable business models should be defined at the level of both single organizations and the whole chain (Varsei et al., 2014). Involvement of public and private economic actors should play a crucial role in 
solving complex and transversal issues about global and regional current agro-food systems, starting from those as weak as the African ones, and their related food value chains. This effort could be able to foster an extensive sustainable economic growth, the preservation of biodiversity, a general improvement in health by affordable food and increased quality of diets, and finally normalization in migration dynamics.

\section{Agricultural productivity and income pathway to improved nutrition}

In the early stages of structural transformation, agricultural productivity growth is a primary driver of rural household income growth and overall economic growth. Consequently, this has a direct impact on household food consumption and the aggregate demand for food. The green revolution (GR) has played a pivotal role in the extra-ordinary rise of agricultural productivity during this period by generating large increases in the productivity of staple crops (Pingali, 2012). It has also been established that the GR has had an unquestionably positive impact on the calorie and protein consumption of the population due to its direct and indirect effects (Fan and Brzeska, 2010). However, this rise in calorie consumption induced by the GR-led growth in staple grain productivity has not always been accompanied by an improvement in nutrition status as measured by micronutrient deficiencies and diet diversity, among other measures. Although agricultural productivity and crop yields increased dramatically, poverty and food insecurity persist in large parts of the developing world (Gomez and Ricketts, 2013, Spielman and Pandya-Lorch, 2010).

Increased income as a result of the GR led to a rise in demand for non-staple foods, such as vegetables, fruit, meat, and dairy products. This rising demand for diet diversity as countries move along the structural transformation pathway is consistent with Bennett's Law. However, the increased demand for non-staples was not always matched by a corresponding increase in their supply. Hence, high relative prices of nonstaple food persisted. Joshi et al., (2004) provide empirical evidence of this phenomenon in the post-GR period in South Asia. A large number of crops, whose relative prices are high compared to staple grains, are especially rich in micronutrients. This limited the impacts of diet diversification on nutrition outcomes (Kataki, 2002). This situation continued well into the post-GR period, and in some cases, worsened due to the persistence of GR policies of staple grain productivity enhancement, while ignoring non-staple food supply. Typically, smallholder farmers have high transaction costs in linking into modern value chains for high-value agricultural products. These costs can be daunting for small farmers and serve as obstacles to their integration into the new food system. Thus, pro-poor policies that connect smallholders to value chains for nonstaple crops could potentially increase income growth and enhance access to nutritious food (Pingali et al., 2015).

In the process of modernizing the agricultural system, it is important to incentivize on-farm diversification through investment in rural market infrastructure and other policy support that helps lower non-staple food prices and increase incomes. The skills needed for nonstaple crop production and sale are quite different from those for staple crops. Reardon et al., (2012) reported that the mismatch of skills needed and skills available as a potential constraint to the production of non-staple crops. This implies that investments need to help people adapt, learn, and implement these new technologies and management practices. Further- more, food security policy has not yet evolved from its focus on calorie sufficiency 
to one that ensures access to a nutritionally balanced and diverse diet. To achieve and sustain a balanced food system, there is a need for a crop-neutral agricultural policy that reduces the bias toward particular staple commodities and lets farmers respond to market signals (Pingali, 2015).

\section{Thinking strategically about rural worlds} and assets

Segmenting these different rural worlds through a markets lens helped Ferris and Seville (2010) to propose segmentation of development interventions.

\section{Livelihood assets}

Studies on the benefits of supply chain participation suggest that a producer's assets are a critical factor in their ability to participate in and benefit from formal markets (Fig. 5). Assets can be seen through three lenses. First, identifying pre-existing assets is important for evaluating the likelihood of a producer benefiting from a trading opportunity. Second, understanding the gap between available assets and those necessary to successfully benefit in the long-term in a particular market is critical to designing the upgrading strategy. Finally, assets themselves are an indicator of poverty and thus a useful metric for evaluating and monitoring the impact of value chains on poverty.

'Assets' cover all the livelihood capitals including human, physical, social, cultural, natural, financial and political. Certain 'productive assets', such as natural, financial and human capital, are widely regarded as key to inclusion in value chains. The Sustainable Livelihoods Framework reminds us that both the use and effectiveness of these capitals is mediated through social, environmental and economic processes. Livelihood strategies thus should be considered holistically and interventions in value chains should be context specific.

Strategies for leveraging a market access opportunity to increase development impact

Although formal value chains offer an economic engine that has the potential to reach and benefit the poor, experience has shown that the full benefits - whether provided via a third-party certified chain or based on private company standards and relationships - require that private sector initiatives be complimented by targeted investment in producer and community assets (Fig. 6). From the evidence and practitioner experience, strategies for increasing benefits to the poor from: (1) investing in upgrading to meet production and processing requirements; (2) adapting trading relationships and supply chain structure for smallholder sourcing; (3) adapting the product proposition and buying practices of the lead firm; and (4) investing in broader sustainable livelihood strategies.

The actual decisions about investing in a market participation opportunity, as well as designing the product proposition and value chain upgrading strategy, must come from the stakeholders in a system. The decisions will be based on their goals and the market opportunities before them. It is

critical to ensure that producers and producer organizations are making informed choices about what they engage in and that they understand the costs, risks, benefits and necessary investments.

\section{Effective market linkages}

Effective market linkages are at the heart of successfully marrying the world of disparate and heterogeneous small-scale producers with the needs of modern markets for consistent 
reliable supplies. No firms in formal markets can afford to source directly from thousands of small-scale producers without effective intermediaries. Intermediary structures include producer cooperatives, private processing companies, lead farmers, independent trader networks and buying hubs. These market linkage intermediaries serve not just to aggregate and process goods to meet the needs of the buyer; they are also essential hubs for services, inputs or quality assurance. In the best cases, they help farmers meet their marketing needs. The role of the intermediary is nested in context, depending on what other services are available, as in the case of agricultural extension services.

Value chain projects focus first and foremost on a successful commercial relationship between smallholders and markets around a limited number of cash crops. The trading relationships focus on commercial viability and more equitable and sustainable trading practices in those crops. Upgrading focuses on building the capacity of famers and intermediaries to meet the needs of the market in terms of quality, consistency, production standards and business practices. All of these interventions help increase net income from the targeted crop, which contributes positively to livelihood improvement. Beyond upgrading, trading relationships and buying practices, evidence from many of the impact studies points to the high potential for increased benefits from additional investments in livelihoods and food security. These sort of horizontal investments leverage the relationships and opportunities created by formal value chain market access (Fig. 7).

Global value chain based formal markets might also offer opportunities for smallholders to tap into fast growing international markets for high value agricultural products. One of the key challenges policymakers, the development community and agribusinesses face, however, is smallholders' limited formal organization ("producer organizations") that aggregate their production and demand for goods and services in order to enable more effective market participation ("aggregation"). Only 5-10\% of farmers globally are estimated to participate in formal producer organizations. This is despite the fact that such organizations have been supported by both policymakers and the development field as a way of tackling poverty and addressing market failures.

The shift towards food production being organized based on global value chains and production networks and the fast dissemination of supermarkets and other modern food retail outlets around the world is creating increased need for smallholders to partake in some form of aggregation mechanism in order to become contributors to the global food system (Fig. 8). Agribusinesses that buy agricultural products have therefore also been encouraging producer organizations as a way to improve their ability to source from smallholders. Nonetheless, of the producer organizations that do exist in emerging economies, only a negligible portion have been able to achieve stable access to the growing global market of high value agricultural products.

The reviews showed that smallholders' perceived price satisfaction is a multidimensional concept and the three dimensions price fairness, price reliability and relative price are important determinants of the producers' trust in the buyer. Moreover, trust moderates the relationship between smallholders' price satisfaction and producer loyalty to the buyer. Moreover, the fairness, closeness and trust are key determinants of supplier/producer performance, while trust plays a moderating role between fairness and producer financial performance. Therefore the collective action through producer 
organizations increases smallholder income and asset holdings thereby reducing rural poverty.

However, although a trend for greater crop specialization among small-scale farmers in India can be observed, they are still often highly diversified, as they generate farm income from a variety of agricultural activities, such as various cereal crops, vegetables, fruits, dairy and other crops.

They are also often engaged in number of nonagricultural activities outside the farm as well. Considering time constraints, particularly of women, farmers who generate a relatively small proportion of their total income from one particular crop may not find that the efforts of participating in a group that promotes this crop outweigh the benefits.

These considerations derive an important policy recommendation. Under certain conditions it may be reasonable for smallscale farmer groups to not focus only on the promotion of a single crop, but instead diversify their portfolio of services to include a range of other agricultural products as well.

Product diversification is a well-known strategy in corporate marketing. Although being potentially motivated by different reasons, product diversification of cooperative organizations can similarly increase profitability, manage risk, and enhance access to new markets. It would further economize on transaction costs and increase benefits for small scale, highly diversified farmers. However, for successful product diversification external support is needed to build up human skills and provide necessary technologies and extension.

Diversification of diets toward protein- and micronutrient rich food provides new opportunities for agriculture-led growth for smallholder farmers while simultaneously raising the quality and diversity of their diets. That said, it is important to realize the role that growth in staple crop productivity has played in ensuring food security in the past and its continued future role in meeting the rising demand of a growing population. There is need to focus on an agricultural policy that ensures a food system that is balanced between staple grains and other nutrient-dense foods. Given the connection between market linkages, economic growth, and dietary diversity, investments that can equip a diverse socio- economic group of farmers to participate are essential. Developing rural markets would additionally imply a break between the production and consumption of smallholders.

A thriving market infrastructure would not only guarantee the continuous supply of a balanced and nutritious diet, but it would also provide the means to purchase it by providing a market for people to sell their produce. This would imply a shift in policy focus from raising diversity on individual farms to concentrating on creating and maintaining an overall balanced food supply system.

Although supply-side policies and institutional investments can expand the availability of diverse foods and enable smallholder income gains, agricultural policies for improved nutrition can also aim to strengthen consumer demand for foods rich in micronutrients and protein. The policy investments in market information technologies, product standardization, and food safety regulations can build consumer trust, identify new market demands, and provide meaningful opportunities for farmer response. Rural extension programs should focus their efforts on promoting short food supply chain based on a bottom up approach that starts with the direct involvement of farmers' associations and smallholders in order to ensure public 
policy efficiency.

Fig.1 Integrate supply chain management and value chain development
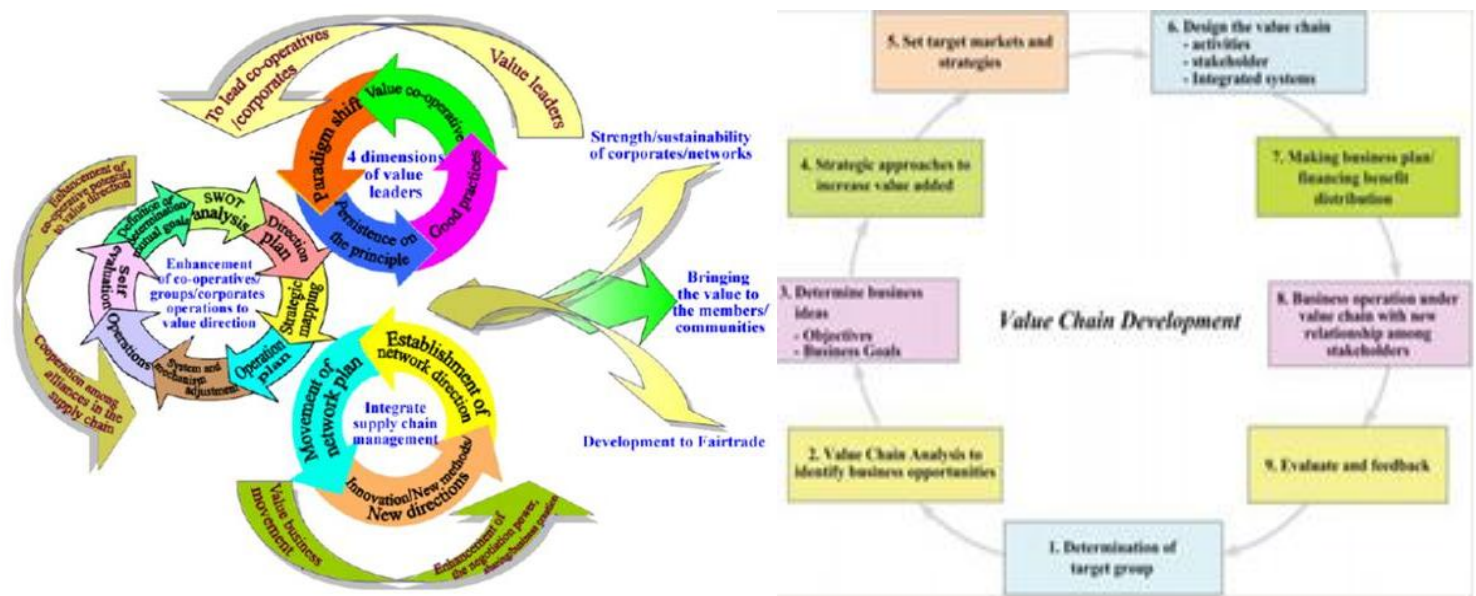

Fig.2 Flows of income and sources of investments in an agricultural smallholding

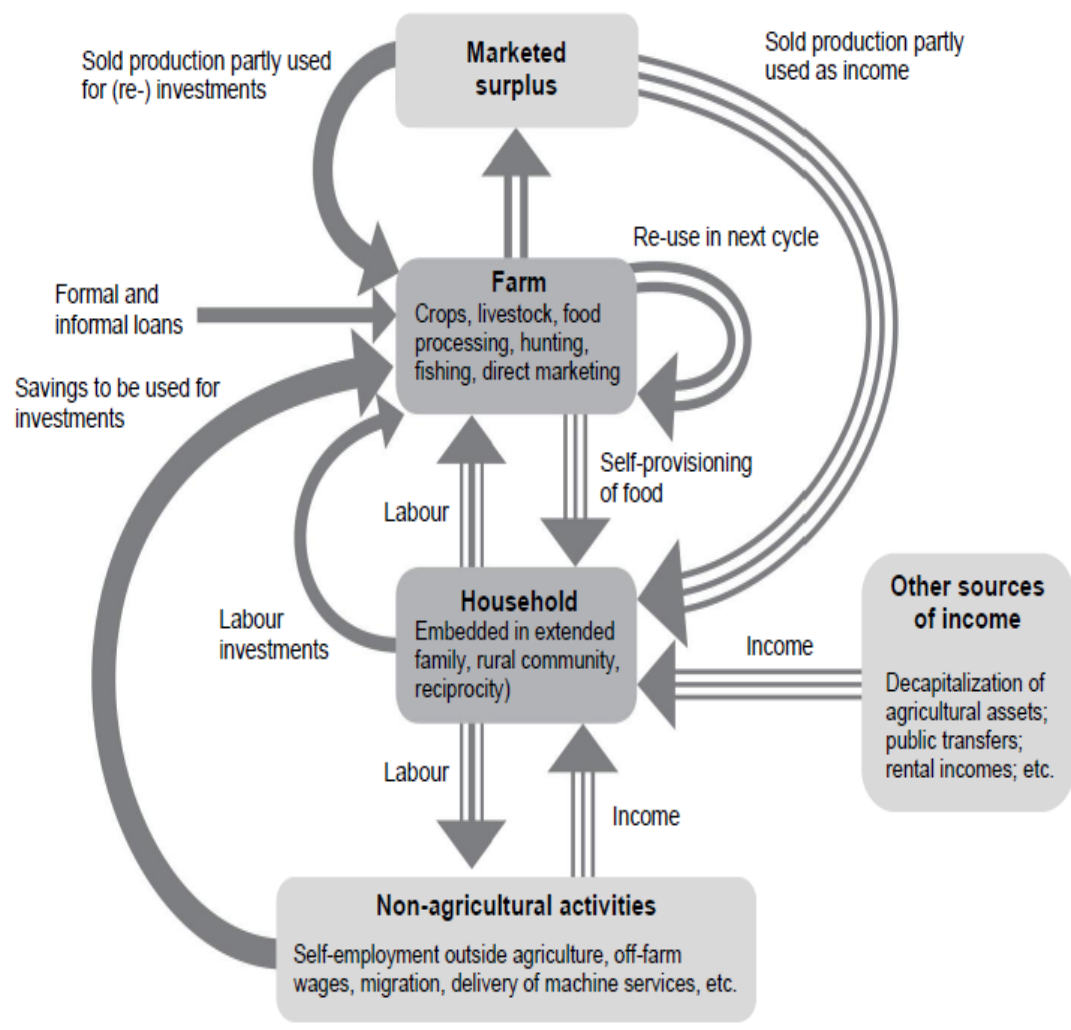


Fig.3 Repartition of holdings by class area and regional diversity of holding size in the 81country subset of FAO-WCA [Source: Beliérès et al., 2013]
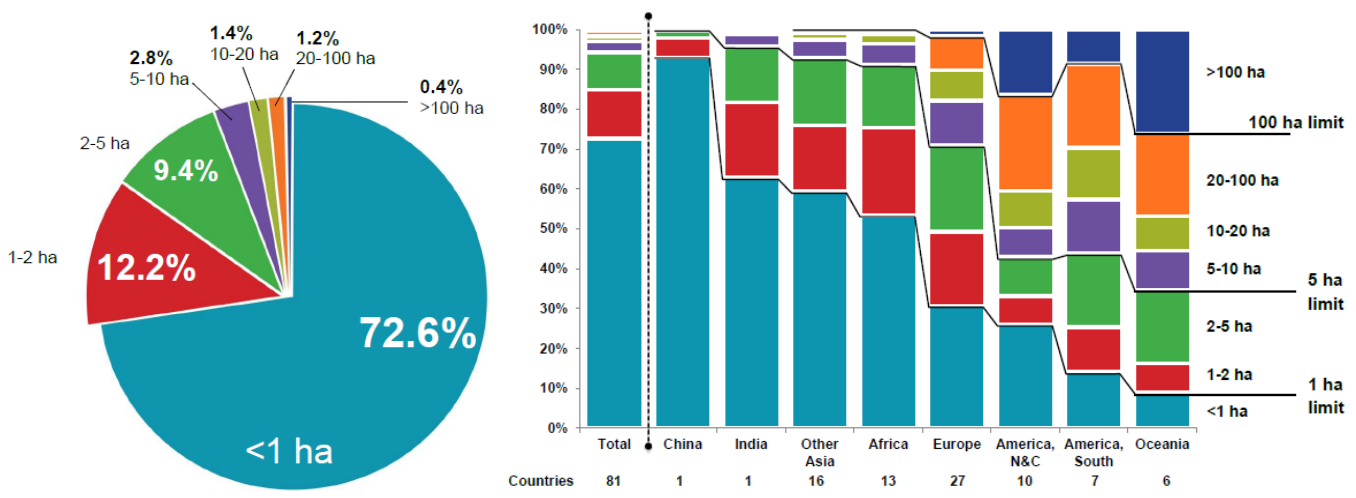

Fig.4 The sustainable food value chain development paradigm

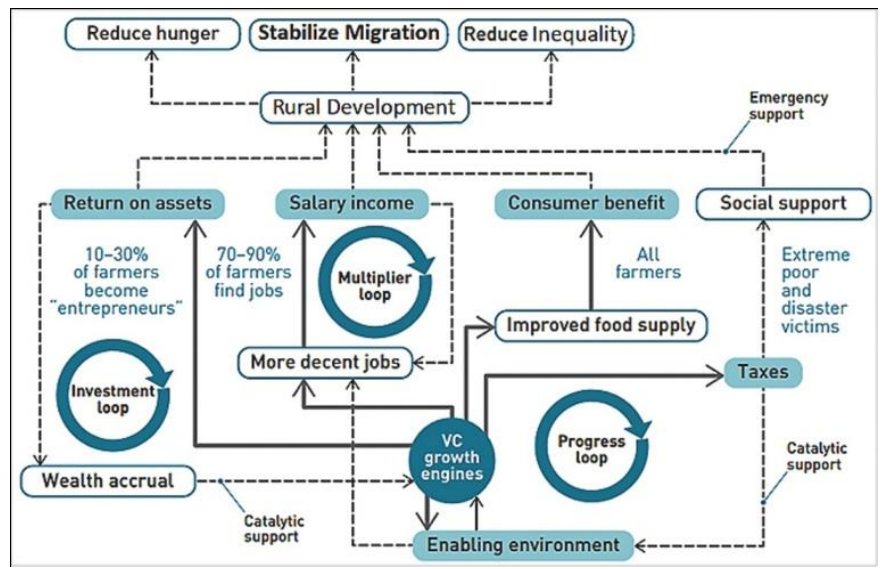

Fig.5 Market participation classes of farmers

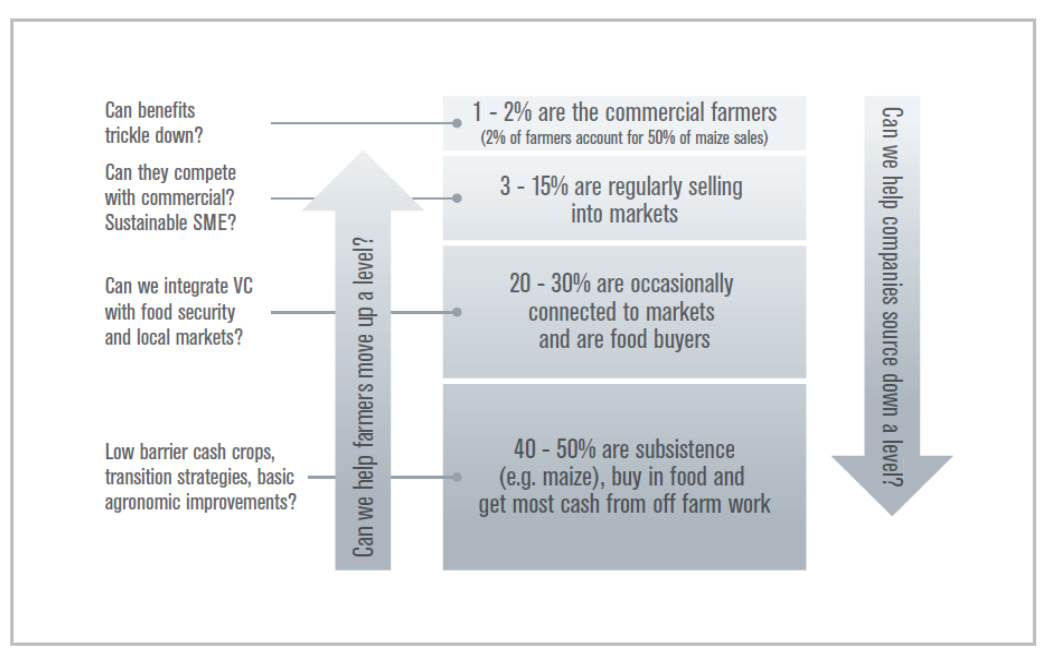


Fig.6 Leverage points in a supply chain

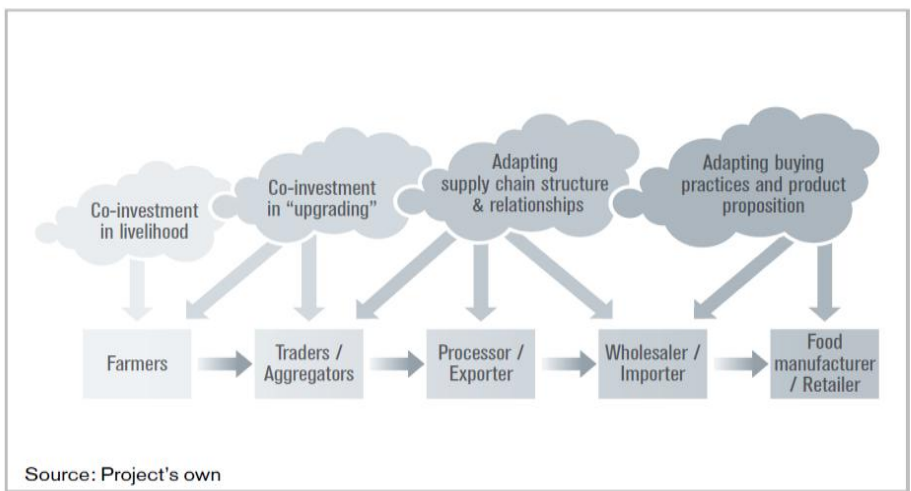

Fig.7 Vertical and horizontal investments

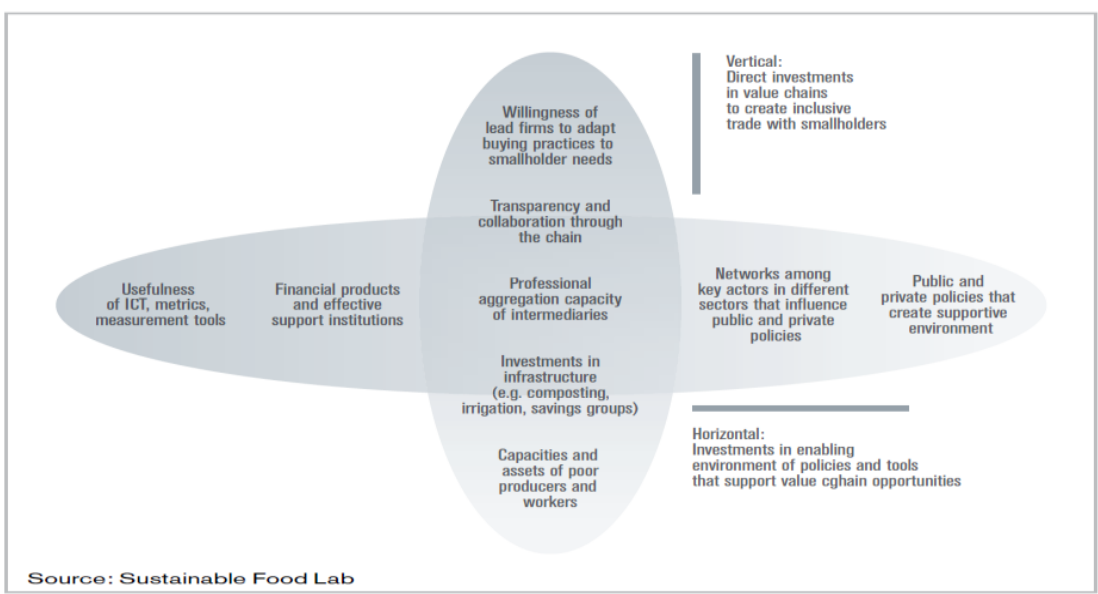

Fig.8 Agricultural and food system value chains

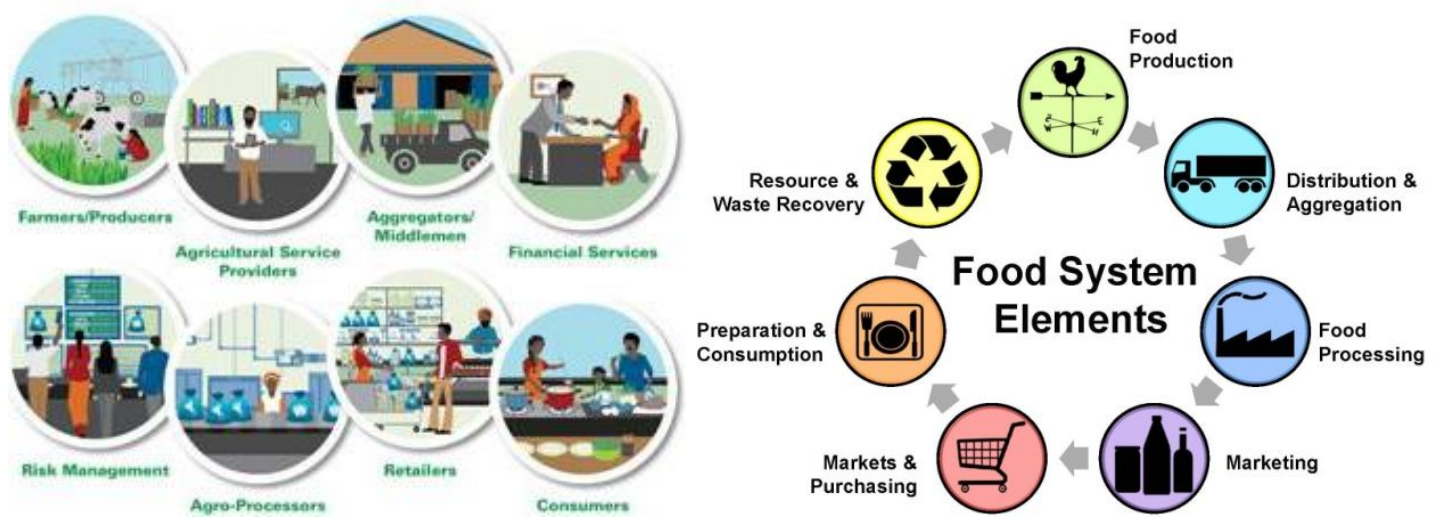




\section{References}

Barrett, C. B. 2008. Smallholder market participation: Concepts and evidence from eastern and southern Africa. Food Policy, 33(4): 299-317.

Bélières, J.-F., Bonnal, P., Bosc, P.-M., Losch, B., Marzin, J. and Sourisseau, J.-M. 2013. Les agricultures familiales du monde. Définitions, contributions et politiques publiques. Montpellier, Paris. CIRAD, AFD.

De Pee S et al., 2017. Nutrition and health in a developing world. Third edition. Humana Press, Rome.

DFID. 2008. The Operational Guide for the Making Markets Work for the Poor (M4P) Approach. London: Department for International Development. www.setoolbelt.org/ resources/1836

Fan S, Brzeska J. 2010. Production, productivity, and public investment in East Asian agriculture. Handb.Agric. Econ. 4:3401-34

Food and Agriculture Organisation. 2014c. developing sustainable food value chains -Guiding principles. Rome.

Francesconi, G. N., and Heerink, N. 2011. Ethiopian agricultural cooperatives in an era of global commodity exchange: does organizational form matter? J Afr Econo, 20(1): 153-177.

Gomez MI, Ricketts KD. 2013. Food value chain transformations in developing countries: selected hypotheses on nutritional implications. Food Policy 42:139-50

Hazell, P. 2011. Five Big Questions about Five Hundred Million Small Farms. Keynote Paper presented at the IFAD Conference on New Directions for Smallholder Agriculture, 24-25 January, 2011.

Hawkes, Corinna and Ruel, Marie.2011). Value Chains for Nutrition. Prepared for the IFPRI 2020 international conference "Leveraging Agriculture for Improving Nutrition and Health," February 10-12, 2011, New Delhi, India

Hellin, J., Lundy, M.; Meijer, M. 2008. Farmer organization, collective action and market access in Meso-America. Food Policy, 34(1):16-22.

Hobbs, J., A. Cooney, and M. Fulton. 2000. Value Chains in the Agri-food Sector: What Are They? How Do They Work? Are They for Me? Saskatoon, Canada: Department of Agricultural Economics, University of Saskatchewan

IFAD and UNEP. 2013. Smallholders, food security and the environment. Rome

Jayne, T. S., Mather, D., and Mghenyi, E. 2010. Principal challenges confronting smallholder agriculture in sub-Saharan Africa. World Development, 38(10):1384-1398.

Joshi PK, Gulati A, Birthal PS, Tewari L. 2004. Agricultural diversification in South Asia: patterns, determinants, and policy implications. Econ. Polit. Wkly. 39 (24): 2457-67

Kataki PK. 2002. Shifts in cropping system and its effect on human nutrition: case study from India. J. Crop Prod. 6(12):119-44

Pingali PL. 2012. Green Revolution: impacts, limits, and the path ahead. PNAS 109 (31): $12302-8$

Patrawart, J. 2007. Value Chain Management, Co-operative Academic Institute Working Paper Series, 2550-012 (http://www.cai.ku.ac.th/article/0122550.

Pingali PL. 2015. Agricultural policy and nutrition outcomes - getting beyond the pre-occupation with staple grains. Food Secur. 7(3):583-91

Porter, M. E., and Kramer, M. R. 2011. 
Creating shared value. Harvard Business Review, January-February: 62-77.

Rao, E. J. O., and Qaim, M. 2011. Supermarkets, farm household income, and poverty: Insights from Kenya. World Development, 39(5): 784-796.

Reardon, T., Barrett, C. B., Berdegue, J. A., and Swinnen, J. F. M. 2009. Agrifood industry transformation and small farmers in developing countries. World
Development, 37(11): 1717-1727.

Varsei, M., C. Soosay, B. Fahimnia, J. Sarkis. 2017. Framing sustainability performance of supply chains with multidimensional indicators Supply Chain Management: An Int. J., 19 (3): $242-257$

Wiggins, S., Kirsten, J., and Llambi, L. 2010. The future of small farms. World Development, 38(10): 1341-1348.

\section{How to cite this article:}

Saurabh Tyagi, R.K. Naresh, A.P. Garg, M. Moni and Abhishek Kumar. 2019. Increasing the Competitiveness of Market Value Chains be Shaped to Improve Nutrition for Smallholder Producers: A Review. Int.J.Curr.Microbiol.App.Sci. 8(11): 2034-2048.

doi: https://doi.org/10.20546/ijcmas.2019.811.236 